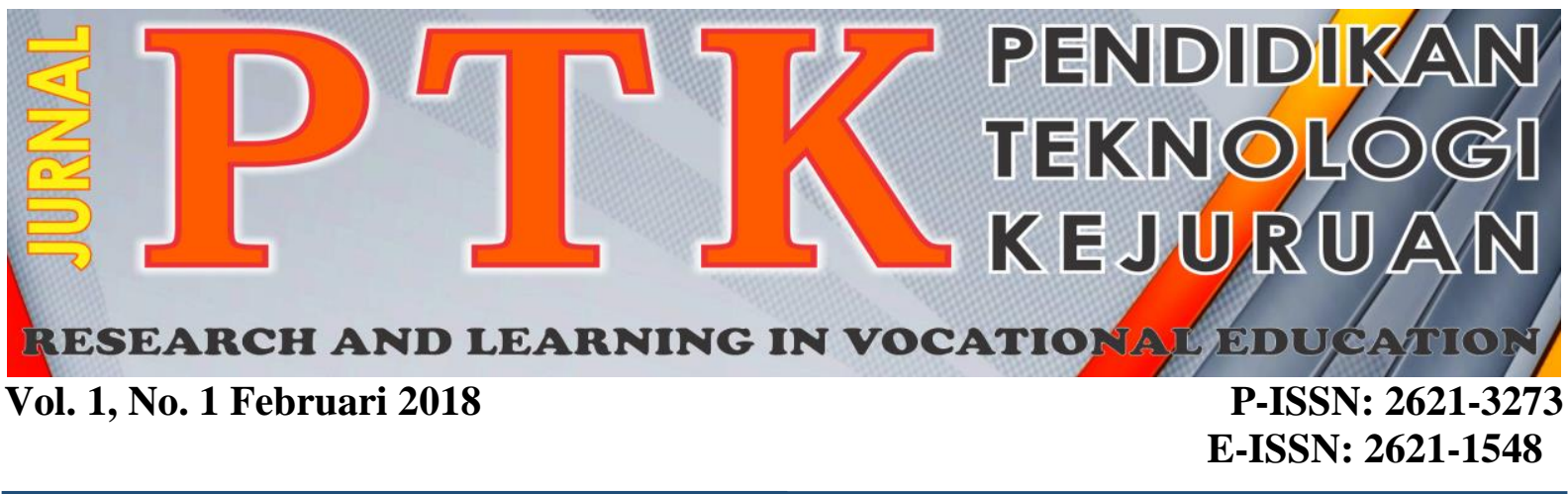

\title{
EVALUASI DAN DISAIN HIPOTETIK PROGRAM PRAKTEK KERJA INDUSTRI (PRAKERIN) SISWA SMK NEGERI 2 PADANG PANJANG
}

\author{
Agamuddin $^{1}$, Fahmi Rizal ${ }^{2}$ dan Fera Susanti ${ }^{3}$ \\ ${ }^{123}$ Program studi Pendidikan Teknologi dan Kejuruan, Fakultas Teknik, Universitas Negeri Padang \\ ${ }^{*}$ Corresponding author, e-mail: fahmi.rizal81@gmail.com²
}

\begin{abstract}
Abstrak - Observasi awal mengindikasikan kompetensi kejuruan yang dipelajari di sekolah kurang sesuai dengan yang didapatkan di tempat prakerin. Tujuan penelitian untuk mengevaluasi bagaimana tingkat pencapaian konteks, masukan, proses dan hasil untuk merumuskan dasar disain hipotetik program prakerin siswa SMK Negeri 2 Padang Panjang. Penelitian deskriptif evaluatif dengan kombinasi kuantitatif dan kualitatif ini menggunakan model CIPP. Instrumen yang dipakai memiliki validitas sebesar 0,361 pada taraf signifikansi 0,05 dan reliabilitas= 0,926. Penelitian menyimpulkan bahwa konteks dalam prakerin ditinjau dari tujuan program dan lingkungan tempat prakerin dinilai cukup baik. Jenis pekerjaan siswa pada saat prakerin dengan kompetensi keahlian siswa di sekolah kurang relevan terutama pada keahlian Program Keahlian Rekayasa Perangkat Lunak. Hasil evaluasi ini dijadikan dasar bagi disain hipotetik pelaksanaan standar prakerin bagi program keahlian Rekayasa Perangkat Lunak untuk masa datang.
\end{abstract}

Kata kunci : evaluasi, prakerin

Abstract-Pre-observation showed that vocational competencies the students studied at school were not relevant to the place where they conducted the industrial attachment (prakerin). This research was to evaluate the context, input, process and product of the prakerin activities, analyzing the causes and then developing a hypotetic design for prakerin program. The research was a quantitative and qualitative research approach. CIPP model evaluation was applied in this study. Validity and reliability of the instrument used in this study were 0,361 and 0,926 at 0.05 significancy level. It was found that context of Prakerin considered from both of program's goal and Prakerin's environment was good. The study confirmed that student's job in Prakerin and the vocational competences studied in school were irrelevant especially on Rekayasa Keahlian Perangkat Lunak program. Based on this study, a hypothetic design had been developed as a standard operational procedure in conducting Prakerin especially for program keahlian Rekayasa Perangkat Lunak.

Keywords: evaluation, industrial experience

Copyright $\odot 2018$ JPTK. All rights reserved

\section{Pendahuluan}

Pemerintah melalui Depdikbud telah mengeluarkan Peraturan Pemerintah (PP) Nomor 29 tahun 1990 tentang pendidikan menengah kejuruan. Tujuan pendidikan kejuruan yang tertuang pada pasal 3 ayat 2 menyatakan, bahwa SMK bertujuan untuk; (1) memasuki lapangan kerja serta mengembangkan sikap profesional, (2) menyiapkan siswa agar mampu memilih karir, mampu berkompetensi dan mampu mengembangkan diri, (3) menyiapkan tenaga kerja tingkat menengah untuk mengisi kebutuhan dunia usaha/industri pada saat ini ataupun masa yang akan datang, dan (4) menyiapkan tamatan agar menjadi warga negara yang produktif, adaptif dan kreatif [1].

Pendidikan Sistem Ganda (PSG) merupakan salah satu implementasi kebijakan "link and match" antara dunia pendidikan dan dunia kerja. PSG menekankan pada pendidikan keahlian profesional yang memadukan secara 
sistematik dan sinkron antara program pendidikan di sekolah dengan program penguasaan kerjadi dunia kerja. Dengan demikian para siswa SMK dengan program PSG ini akan memiliki tingkat profesional yang relevan dengan dunia kerja yang dibutuhkan.

Menurut Indra Djati Sidi, tujuan dari pelaksanaan PSG adalah:

1. Menghasilkan tenaga kerja yang memiliki keahlian professional, yaitu tenaga kerja dengan tingkat kemampuan, kompetensi, dan etos kerja yang sesuai dengan tuntutan lapangan kerja.

2. Meningkatkan dan memperkokoh link and match antara lembaga pendidikan/pelatihan kejuruan dan dunia kerja.

3. Meningkatkan efisiensi proses pendidikan dan pelatihan tenaga kerja berkualitas profesional dan

4. Memberi pengakuan dan penghargaan terhadap pengalaman kerja sebagai bagian dari proses pendidikan [2].

Sebagai wujud nyata dari pelaksanaan PSG adalah dilaksanakannya program praktek kerja industri (Prakerin). Prakerin merupakan suatu kegiatan belajar di dunia kerja dan industri (Dudi) untuk memberikan siswa kesempatan memahami dan mendalami kemampuan yang didapat di sekolah dalam keadaan dan situasi kerja yang sesungguhnya.

Pelaksanaan prakerin SMK Negeri 2 Padang Panjang menggunakan sistem catur wulan (block release) yang dilaksanakan pada semester ke IV. SMK Negeri 2 Padang Panjang memiliki tiga Program Keahlian, yaitu Rekayasa Perangkat Lunak, Teknologi Komputer Jaringan dan Multimedia. Berdasarkan pengamatan peneliti dan informasi dari siswa SMK Negeri 2 Padang Panjang yang telah melaksanakan prakerin, diketahui bahwa pelaksanaan prakerin belum meningkatkan kompetensi siswa. Hal ini disebabkan karena sering terjadinya kendala pada pelaksanaan prakerin.

Adapun kendala yang dimaksud dapat dilihat dari segi tujuan dan lingkungan pelaksanaan prakerin. Menurut Depdiknas salah satu tujuan prakerin adalah implementasi kompetensi ke dalam dunia kerja [3]. Kemampuan-kemampuan yang sudah dimiliki peserta didik, melalui latihan dan praktik di sekolah perlu diimplementasikan secara nyata sehingga tumbuh kesadaran bahwa apa yang dimilikinya berguna bagi dirinya dan orang lain.
Tetapi kenyataan yang terjadi di lapangan aktifitas siswa banyak melakukan pekerjaan yang kurang sesuai dengan kompetensi yang dimilikinya, seperti mengantar surat, mengetik, fotocopy atau pekerjaan yang dibutuhkan oleh DU/DI. Situasi seperti ini terjadi dari tahun ke tahun.

Di samping itu keterbatasan daya tampung dari Dudi yang rata-rata hanya bersedia menerima siswa sekitar 2 sampai 3 orang mengakibatkan siswa harus ditempatkan di Dudi atau institusi yang kurang sesuai dengan kompetensi keahlian siswa, tetapi bersedia menerima melaksanakan prakerin. Kendala juga dapat dilihat dari faktor pendukung pelaksanaan prakerin. Terjadi keterbatasan pengetahuan, pengalaman serta latar belakang supervisor atau pembimbing di Dudi yang tidak memenuhi tuntutan kompetensi. Selain itu bimbingan yang kurang optimal dari guru pembimbing di sekolah juga memberikan dampak kurang baik terhadap pelaksanaan prakerin. Keterbatasan waktu bimbingan selama prakerin juga mengakibatkan siswa kurang mendapatkan arahan. Faktor lain yang juga berpengaruh pada pelaksanaan prakerin adalah kemampuan dari siswa itu sendiri. Siswa yang memiliki kemampuan akademik yang kurang, biasanya memiliki sifat kurang percaya diri pada saat prakerin. Di samping itu disiplin kerja, sikap serta inisiatif siswa yang masih rendah.

Masalah lain yang ditemukan adalah pelaksanaan program prakerin belum berjalan secara sistematis dan efektif dikarenakan waktu pelaksanaannya tidak sesuai dengan program di Dudi. Belum adanya evaluasi yang optimal terhadap program prakerin selama ini mengakibatkan permasalahan yang sama terjadi lagi pada tahun berikutnya. Hal ini juga mengakibatkan sulitnya mengukur kualitas pelaksanaan prakerin. Apalagi penilaian siswa hanya dari segi kognitif dan afektif saja bukan dari psikomotorik.

Dari uraian di atas dapat diketahui bahwa tujuan dari pelaksanaan program prakerin belum tercapai. Untuk memastikan tercapai atau tidaknya sebuah program perlu dilakukan sebuah kegiatan yang berwujud evaluasi program. Tujuan akhir dari evaluasi program adalah untuk memperbaiki tingkat efektifitas program. Berdasarkan hasil evaluasi program tersebut, peneliti mencoba untuk mendisain hipotetik program prakerin yang baru.

\section{Metode Penelitian}

Penelitian ini merupakan kombinasi penelitian kuantitatif kualitatif (sequential 
explanatory mixed methods) dengan menggunakan pendekatan deskriptif evaluatif. Dalam penelitian ini, digunakan model CIPP (Contex, Input, Process, Product). Metode kuantitatif digunakan untuk memperoleh data tingkat pencapaian responden dan metode kualitatif dalam bentuk wawancara mengklarifikasi temuan kuantitatif tadi.

Tujuan akhir penelitian ini adalah mengevaluasi dan membuat disain hipotetik program prakerin. Lokasi penelitian bertempat di SMK Negeri 2 Padang Panjang. Populasi penelitian terdiri dari 188 siswa yang duduk di enam kelas XII Program Studi Keahlian Teknik Komputer Jaringan, Rekayasa Perangkat Lunak dan Multimedia tahun pelajaran 2011-2012 yang telah mengikuti program Prakerin. Pengambilan sampel dilakukan secara Proportional Random Sampling dengan jumlah sampel sebesar 48orang.

Teknik pengumpulan data yang digunakan dalam penelitian ini adalah kuesioner, wawancara dan observasi langsung ke lapangan. Pengujian instrumen dilakukan dengan uji validitas dan reliabilitaas. Analisis data yang digunakan adalah statistik deskriptif, yaitu teknik yang digunakan untuk mendeskripsikan atau memberi gambaran terhadap objek yang diteliti melalui data sampel atau populasi. Data yang terkumpul dianalisa secara kuantitatif dan selanjutnya dijelaskan secara kualitatif. Pertama kali dilakukan penghitungan frekuensi jawaban responden berdasarkan angket yang dibagikan. Angka frekuensi ini lalu diolah menggunakan metode penghitungan Tingkat Pencapaian [4]. Selanjutnya tingkat pencapaian yang dinilai kurang dijadikan bahan wawancara dengan guru dan pihak terkait lainnya untuk memastikan penyebabnya.

\section{Hasil Penelitian dan Pembahasan}

Hasil analisis data menunjukkan bahwa program Prakerin SMKN 2 Padang Panjang sudah berjalan dengan baik. Tetapi masih ada pelaksanaan sub variabel yang belum sesuai dengan yang diharapkan. Hal ini dapat dilihat dari hasil perolehan data yang penulis dapatkan.

Analisis deskriptif terhadap variabel context yang terdiri dari indikator tujuan program prakerin dan lingkungan tempat prakerin. Dari 48 siswa diperoleh skor rata-rata 30,96 dari skor maksimum ideal 40, dengan tingkat ketercapaian sebesar 77,40\%. Artinya tujuan program prakerin cukup sesuai dengan kebutuhan siswa karena program prakerin dapat meningkatkan kemampuan kompetensi produktif, meningkatkan disiplin kerja, dan memberikan pengalaman kompetensi produktif sesuai dengan bidang keahlian yang dimiliki siswa. Tetapi pada pelaksanaan prakerin, belum sepenuhnya sesuai dengan tujuan. Pada indikator lingkungan tempat prakerin diperoleh skor rata-rata 30,82 dari skor maksimal 40, dengan tingkat ketercapan sebesar $77,40 \%$ dengan kategori cukup. Artinya lingkungan tempat prakerin belum sesuai dengan kompetensi keahlian.

Mengenai kondisi lingkungan industri tempat siswa melaksanakan prakerin menurut salah satu siswa yang peneliti himpun dari siswa jurusan multimedia yang mengikuti kegiatan prakerin di Padang menyatakan bahwa tempat melakukan prakerin kurang sesuai kompetensi keahlian yang dimilikinya. Hal ini membuktikan bahwa tujuan program prakerin dan lingkungan tempat prakerin sangar berpengaruh dalam meningkatkan kompetensi siswa. Hal ini kurang sesuai dengan yang ditetapkan Depdiknas, (2005:3) tentang klasifikasi industri prakerin antara lain : a) memiliki fasilitas sesuai dengan standar kompetensi, b) bidang usaha yang sesuai dengan kompetensi siswa. Masukan (input) dalam program praktik kerja industri siswa SMK Negeri 2 Padang Panjang ditinjau dari arahan bimbingan sekolah dan DU/DI, kekuatan peserta didik dan dana prakerin.

Berdasarkan hasil analisis deskriptif indikator arahan bimbingan sekolah dan DU/DI siswa SMK Negeri 2 Padang Panjang dari 48 orang siswa diperoleh skor rata-rata 37,44 dari skor maksimal 50, dengan tingkat ketercapaian sebesar 74,88\% dengan kategori cukup. Artinya siswa yang mengikuti prakerin cukup mendapatkan bimbingan baik dari guru pembimbing maupun dari pembimbing DU/DI. Hal tersebut didukung dengan hasil wawancara peneliti dengan salah seorang pembimbing lapangan yang menyatakan bahwa selama prakerin siswa mendapatkan bimbingan dari pembimbing lapangan. Tujuaannya adalah agar siswa dapat melakukan prakerin secara terstruktur. Tetapi terdapat masalah pada siswa yang memiliki program keahlian yang kurang relevan dengan pekerjaan di DU/DI. Untuk mengatasi hal tersebut, pembimbing lapangan memberikan pengarahan dan bimbingan meskipun kurang sesuai dengan program keahlian. Sementara untuk guru pembimbing di sekolah tidak selalu memberikan bimbingan. Dan hal ini hanya dilakukan pada saat monitoring dan pembimbingan laporan pada saat siswa telah 
menyelesaikan prakerinnya. Berdasarkan uraian tersebut diatas, dapat disimpulkan bahwa terdapatnya perbedaan kompetensi yang dimiliki siswa dengan pekerjaan di DU/DI, sehingga pada saat pelaksanaan prakerin pembimbing di DU/DI harus memberikan ilmu tambahan kepada siswa prakerin.

Berdasarkan hasil analisis deskriptif indikator kekuatan peserta didik siswa SMK Negeri 2 Padang Panjang dari 48 orang siswa diperoleh skor rata-rata 31,98 dari skor maksimal 40, dengan tingkat ketercapaian sebesar 79,95\% dengan kategori cukup. Artinya siswa yang mengikuti prakerin memiliki kemampuan dalam melaksanakan prakerin, memiliki disiplin yang tinggi dan mengetahui tujuan pelaksanaan prakerin.

Hal tersebut didukung dengan hasil wawancara dengan pembimbing sekolah bahwa kriteria siswa yang mengikuti program prakerin adalah siswa yang sudah menuntaskan kompetensi baik itu adaptif, normatif maupun produktif. Selain itu siswa diwajibkan mengikuti seluruh program orientasi sebelum melaksanakan prakerin. Tujuannya adalah untuk melatih siswa untuk mampu berkomunikasi dan bekerja sama, meningkatkan disiplin kerja serta memperkenalkan DU/DI secara umum.

Berdasarkan uraian tersebut diatas, dapat disimpulkan bahwa pentingnya dilakukan pembinaan sebelum melaksanakan prakerin, sehingga siswa sudah memahami apa yang harus dilakukan pada saat prakerin.

Indikator dana prakerin diperoleh skor ratarata 17,95 dan skor maksimal ideal 25 dan tingkat ketercapaian sebesar $71,75 \%$ dengan kategori cukup. Artinya pemanfaatan dana prakerin disesuaikan dengan kebutuhan prakerin, dan diketahui oleh orang tua siswa untuk keperluan apa saja biaya prakerin yang diminta, supaya tidak terjadi pemikiran negatif dari orang tua siswa.

Berdasarkan hasil analisis deskriptif diperoleh indikator persiapan pelaksanaan prakerin dengan skor rata-rata 60,71 dengan kategori cukup. Artinya persiapan pelaksanaan prakerin yaitu pembekalan prakerin sangat menunjang terhadap pelaksanaan program prakerin.
Indikator pelaksanaan program prakerin diperoleh skor rata-rata 17,90 dan skor maksimal ideal 25, serta dengan tingkat ketercapaian sebesar $71,58 \%$ dengan kategori cukup. Artinya pelaksanaan prakerin belum dapat meningkatkan kompetensi siswa. Untuk menguatkan hasil temuan didukung oleh wawancara dengan pembimbing di DU/DI bahwa kurang relevannya kompetensi siswa dengan pekerjaan yang ada di DU/DI. Siswa lebih banyak belajar pada kompetensi dasar kejuruan. Berikut menurut wakil kurikulum, pelaksanaan prakerin tidak sepenuhnya yang relevan dengan kompetensi kejuruan. Hal ini disebabkan terbatasnya penerimaan oleh DU/DI.

Indikator evaluasi pelaksanaan prakerin diperoleh skor rata-rata 19,60 dan skor maksimal ideal 30 dengan tingkat ketercapaian sebesar $65,35 \%$. Artinya pelaksanaan program prakerin dapat menambah kompetensi di DU/DI. Hasil (product) yang telah dicapai dari program praktek kerja industri siswa SMK Negeri 2 Padang Panjang. Berdasarkan data hasil penelusuran terhadap siswa yang telah mengikuti prakerin dapat disimpulkan bahwa pelaksanaan prakerin tidak meningkatkan nilai kejuruan siswa. Hal ini membuktikan bahwa secara output prakerin terbukti belum mampu meningkatkan kompetensi keahlian siswa.

Disain hipotetik atau biasa disebut model hipotetik merupakan hasil analisis komparasi antara hasil studi pendahuluan yang relevan (model konseptual) dengan temuan disain model lapangan (model factual).

Berdasarkan hasil penelitian baik secara kuantitatif maupun kualitatif, diketahui bahwa pelaksanaan prakerin secara umum belum sesuai dengan yang diharapkan. Dari tiga program keahlian yaitu Teknik Komputer \& Jaringan, Rekayasa Perangkat Lunak dan Multimedia ternyata program keahlian Rekayasa Perangkat Lunak (RPL) yang paling kurang relevan dengan kompetensi kejuruan.

Deskripsi hasil evaluasi pelaksanaan program prakerin dengan menggunakan model CIPP, dapat dilihat pada tabel dibawah ini :

Tabel 1. Hasil Evaluasi Prakerin

\begin{tabular}{|c|c|}
\hline Aspek & Temuan Hasil Evaluasi Prakerin \\
\hline Konteks (Context) & $\begin{array}{l}\text { - Terbatasnya daya tampung di DU/DI yang tidak sebanding dengan jumlah } \\
\text { siswa mengakibatkan siswa ditempatkan di DU/DI yang tidak relevan dengan } \\
\text { kompetensi siswa }\end{array}$ \\
\hline
\end{tabular}




\begin{tabular}{lll}
\hline Masukan (Input) & - Keterbatasan pengetahuan, pengalaman serta latar belakang instruktur di \\
& DU/DI \\
& - Keterbatasan bimbingan dari guru pembimbing \\
& - Kemampuan akademik, disiplin kerja, sikap serta inisiatif siswa yang rendah \\
\hline Proses(Process) & - Materi pembekalan siswa belum sepenuhnya sesuai dengan kegiatan siswa di \\
& DU/DI \\
& - Pekerjaan siswa di DU/DI belum sepenuhnya dengan kompetensi yang \\
& diajarkan di sekolah \\
\hline Hasil (Product $)$ & - & Nilai prakerin \\
\hline
\end{tabular}

Merujuk dari data hasil penelitian tersebut, agar tujuan prakerin dapat tercapai secara maksimal, peneliti mencoba mendisain hipotetik program prakerin. Disain hipotetik program prakerin dibatasi untuk Program Keahlian

Tabel 2. Disain Hipotetik Program Prakerin

\begin{tabular}{lll}
\hline \multicolumn{1}{c}{ Aspek } & \multicolumn{1}{c}{ Disain Hipotetik Program Prakerin } \\
\hline Konteks (Context) & - Menganalisis pencapaian tujuan kompetensi keahlian sehingga \\
& pada tujuan pelaksanaan prakerin tepat sasaran \\
\hline Masukan (Input) & - Bimbingan DU/DI \\
& - Bimbingan guru kejuruan \\
& - Kompetensi Siswa \\
& - Sarana \\
\hline Proses (Process) & - Meningkatkan kompetensi siswa sebelum melaksanakan prakerin \\
& - Menyusun buku panduan prakerin yang berisikan tentang tahapan \\
& dalam membuat Perancangan Sistem Informasi \\
\hline Hasil (Product) & - Uji kompetensi hasil pelaksanaan prakerin siswa berupa APSI \\
\hline
\end{tabular}

Menurut Depdiknas, salah satu tujuan prakerin adalah mengimplementasi kompetensi ke dalam DU/DI [3]. Kemampuan-kemampuan yang sudah dimiliki peserta didik, melalui latihan dan praktik di sekolah perlu diimplementasikan secara nyata sehingga tumbuh kesadaran bahwa apa yang dimilikinya berguna bagi dirinya dan orang lain. Dengan begitu peserta didik akan lebih percaya diri karena orang lain dapat memahami apa yang dipahaminya dan pengetahuannya diterima oleh masyarakat.

Pada disain hipotetik program prakerin dari segi konteks yakni melakukan analisis tujuan kompetensi kejuruan, perlu memfokuskan kompetensi apa saja yang harus dilaksanakan dan menentukan target kompetensi [5]. Dalam hal ini, Program Keahlian Rekayasa Perangkat Lunak (RPL) memiliki tujuan kompetensi mampu membuat database dan program aplikasi berbasis web.

Untuk tercapainya tujuan kompetensi ini, maka dibutuhkan bimbingan dari DU/DI. Pembimbing lapangan membantu siswa untuk menginformasikan kebutuhan apa saja yang diperlukan dalam membuat sistem informasi. Selama prakerin ini dibutuhkan bimbingan
Rekayasa Perangkat Lunak (RPL), karena berdasarkan fakta di lapangan jurusan ini paling tidak relevan. Berikut merupakan disain hipotetik program prakerin : berkala dari guru pembimbing baik secara langsung maupun secara online.

Sebelum melaksanakan prakerin, siswa haruslah sudah menguasai kompetensi dalam mata diklat terkait tersebut. Dalam pelaksanaan prakerin, siswa melakukan kegiatan sesuai dengan program sekolah berupa penulisan jurnal. Siswa membuat suatu studi kasus yang terdapat di DU/DI berupa APSI (Analisis Perancangan Sistem Informasi) dan diaplikasikan dalam bentuk program (Software). APSI yang dilakukan ini terdiri dari membuat APSI baru dan menganalisis APSI yang telah ada. Dengan ada disain hipotetik ini, siswa mampu untuk memberikan kontribusi pada DU/DI yaitu berupa program aplikasi yang bisa digunakan oleh DU/DI.

Untuk mengevaluasi pelaksanaan prakerin ini dapat dilihat dari produk yang dihasilkan siswa. Siswa dikatakan kompeten bila siswa telah mampu menghasilkan suatu program (Software) yang dapat digunakan oleh DU/DI tempat mereka prakerin tersebut.

Dari uraian di atas, dapat ditarik kesimpulan bahwa Program Keahlian Rekayasa Perangkat Lunak (RPL) melakukan prakerin dengan mengimplementasikan ilmu yang telah 
dipelajari di sekolah [4]. Di DU/Diitu, siswa membuat suatu Analisis Perancangan Sistem Informasi (APSI) yang diaplikasikan dalam bentuk program (Software), yang dapat membantu DU/DI tempat mereka prakerin. Dengan adanya tahap-tahap pelaksanaan atau disain hipotetik yang konkrit ini diharapkan dapat mengatasi masalah yang ditemukan sebelum penelitian ini dilangsungkan.

\section{SIMPULAN DAN SARAN}

Kesimpulan yang dapat ditarik dari hasil penelitian adalah pelaksanaan prakerin belum sepenuhnya berjalan dengan baik. Tempat pelaksanaan prakerin siswa kurang sesuai dengan bidang keahlian yang dipelajari. Berdasarkan analisis data dan hasil wawancara, diperlukan disain hipotetik program prakerin SMK Negeri 2 Padang Panjang.

Berdasarkan temuan yang diperoleh dalam penelitian ini, maka dikemukakan saran-saran sebagai berikut:

1. Kepala Sekolah beserta pengelola prakerin dapat:

a. Mengenalkan sekolah dengan program keahlian yang ada pada dunia kerja dan industri dengan melakukan promosi yaitu menyebarkan brosur ke dunia kerja yang berisikan kompetensi yang dimiliki siswa

b. Kepala Sekolah beserta pengelola prakerin dapat meninjau kembali pelaksanaan prakerin dan dapat mempertimbangkan kemungkinan penerapan disain hipotetik

2. Guru pembimbing prakerin diharapkan dapat melakukan bimbingan laporan yang sesuai jurnal kepada siswa, dan melakukan ujian dilapangan sehingga pelaksanaan prakerin lebih terarah sesuai dengan program keahlian

3. Siswa perlu ditingkatkan kompetensi keahliannya, supaya pelaksanaan prakerin tercapai sesuai dengan tujuan.

4. Perlu dilakukan penelitian lebih lanjut guna melihat efektifitas disain hipotetik program prakerin Program Keahlian Rekayasa Perangkat Lunak.

\section{DAfTAR Pustaka}

[1] Depdiknas. Peraturan Pemerintah (PP) Nomor 29 Tahun 1990 Tentang Pendidikan Menengah Kejuruan: Jakarta. 1990.

[2] Sidi, I. Djati. Menuju Masyarakat Belajar Menggagas Paradigma Baru Pendidikan. Paramadina. Jakarta, 2001

[3] Depdiknas. Pelaksanaan Prakerin. Jakarta. 2008.

[4] Suharsimi Arikunto. Prosedur Penelitian. Jakarta: Rineka Cipta. 1997

[5] Lismaizarni. Evaluasi program praktek kerja industri di SMK Negeri 1 Padang Panjang. 2011. 